\title{
Effect of Episiotomy on Perineal Lacerations in Spontaneous Vertex Deliveries
}

\section{U NISA}

Department of Obstetrics \& Gynaecology. Services Institute of Medicine Services Hospital, Lahore Correspondence to Dr. Meher un Nisa, Senior Registrar E-mail Address mehersajawal@hotmail.com

Objectives: To evaluate the effects of episiotomy on the frequency of perineal lacerations. Design: Cross-Sectional analytical study. Place \& duration of study: Department of Gynae Obstetrics unit III. Lady willingdon Hospital Lahore. From April 1994 to march 1996. Patients \& methods: 2918 women who delivered vaginally were included in the study. Only right mediolateral episiotomy incision was used in these cases. Local anaesthesia in the form of $2 \%$ Lignocain was used in all cases to infiltrate the area before episiotomy cut. The delivery was conducted in most cases by a resident. The rate of perineal lacerations with or without episiotomy in both primiparae and multiparae groups was noted. Results 2918 women of term singleton babies were entered into this study. Episiotomy was performed in $1419(48.63 \%)$ of these women. There were $1095(37.53 \%)$ primiparae and $1823(62.47 \%)$ multiparae in the study groups. The rate of episiotomy in primiparae and multiparae were $93.42 \%$ and $21.72 \%$ respectively. A total of $267(9.2 \%)$ perineal tears were sustained by these women during vaginal delivery. Episiotomy was associated with $151(10.6 \%)$ perineal tears compared to $116(7.7 \%)$ without episiotomy. The incidence of fourth degree perineal laceration was $0.4 \%$ without episiotomy but increased to $1 \%$ with the use of episiotomy. This difference is statistically significant. Conclusion: Episiotomy is not protective against severe perineal lacerations. A selective use of episiotomy is recommended for appropriate indications.

Key words: Episiotomy, Perinedl Tears, Primiparae, Multiparae.

The episiotomy is the most commonly performed surgical procedure in modern obstetrics. About $63 \%$ of vaginal deliveries are accomplished with this procedure (Thorp et al. 1987). The mean episiotomy rates vary from $28 \%$ to $62 \%$ (Henriksen et al. 1992). The episiotomy rate can reach up to $95 \%$ in case of primigravidae (Wilcox et al. 1989).

A variety of benefits have been claimed for this procedure including substitution of a straight surgical incision for a ragged laceration (Cunningham et al. 1989), prevention of trauma to fetal head, reduction of perineal lacerations and prevention of subsequent pelvic relaxation (Thorp et al. 1989). There is little evidene to support these claims. Concurrently, the usefulness of episiotomy in reducing maternal risks has been challenged (Thacker \& Banta. 1983).

Lacerations of the perineum are frequent complications of vaginal deliver. Compelete tear of the anal sphincter and rectal mucosa can also be sustained during the course of vaginal delivery. Reported incidence of severe perineal lacerations vary considerably ranging from $0-23.9 \%$ (Haadem et al. 1988).

The aetiology of severe perineal lacerations is multifactorial. The risk factors include parity, prolonged second stage of labour, instrumental deliveries, malpositions, shoulder dystocia, macrosomia, obstetrician's status, Asian races and lithotomy position (Combs et al. 1990). Episiotomy cannot be expected to alleviate all these factors. Furthermore,as stated above, many studies have incriminated episiotomy itself as a predisposing factor for severe perineal lacerations.

So this study was performed in Unit-III Lady Willingdon Hospital Lahore to report our own experience about the effects of episiotomy in our population.

\section{Patients \& methods:}

The study sample included women who delivered vaginally in Unit-III Lady Willingdon Hospital, Lahore,during the period between April 1994 and March 1996. Women with singleton pregnancy of at least 37 weeks gestation and cephalic presentation undergoing spontaneous vertex deliveries were included in this study. Women with caesarean sections, twin, breech and instrumental deliveries were excluded from the analysis to eliminate any contributory effect of these confounding variables. Only right mediolateral episiotomy incision was used in these cases. The decision to perform episiotomy in any case was left to the judgment of attending obstetricians. Local anaestheesia in the form of $2 \%$ lignocain was used in all cases to infiltrate the area before episiotomy cut. The delivery was conducted in most cases by a resident.

The data on maternal and infant factors were recorded on a proforma. The information for each woman regarding age, parity, gestational age, duration of second stage of labour, birthweight, Apgar score and indication of episiotomy was recorded. The type of perineal injury sustained during delivery was recorded as main outcome measure. The perineal lacerations for this study were classified into first, second, third and fourth degree. Extension through the rectal wall is distinguished as fourth-degree laeration due to increased possibility of rectovaginal fistulae after such injury.

For the purpose of comparison, the women were divided into primparae and multiparae groups. These groups were further subdivided whether or not the episiotomy was performed. The rate of perineal lacerations in each group was recorded separately. The $\%^{2}$ analysis was used to examine the differences in the incidence of episiotomy and 
perineal lacerations between groups. $\mathrm{P}<0.05$ was considered as statistically significant.

\section{Results:}

During this two years study, 2918 women with term singleton babies were entered into this study. Episiotomy was performed in $1419(48.63 \%)$ of these women. There were 1095 (37.53\%) primiparae and 1823 (62.47\%) multiparae in the study groups. The rates of episiotomy in primiparae and multiparae were $93.42 \%$ and $21.72 \%$ respectively. Table-I enlists the important clinical characteristics of the women in primiparous and multiparaous groups.

Table-II gives a list of indications for performing episiotomy in our labouring women In $47.6 \%$ of cases the procedure was carried out to protect the perineum, to facilitates second stage of labour in $22.1 \%$, to expedite delivery in $13.1 \%$ cases and no indication for episiotomy was registered in $17.2 \%$ of deliveries.

A total of $267(9.2 \%)$ perineal tears were sustained by these women during vaginal delivery. Episiotomy was associated with $151(10.6 \%)$ perineal tears compared to $116(7.7 \%)$ without episiotomy. This difference is statistically significant. Table-III indicates the incidence of various degrees of perineal lacerations with or without episiotomy in total study population. The incidence of fourth degree perineal lacerations was $0.4 \%$ without episiotomy but increased to $1 \%$ with the use of episiotomy. This difference is statistically significant.

Table-I: Clinical characteristics of the women in two study groups.

\begin{tabular}{lll} 
Variables & $\begin{array}{l}\text { Primipara } \\
(1095)\end{array}$ & $\begin{array}{l}\text { Multipara } \\
(1823)\end{array}$ \\
\hline $\begin{array}{l}\text { Frequency of episiotomy } \\
\text { (No. (\%)) }\end{array}$ & $21.72 \%$ & $93.42 \%$ \\
$\begin{array}{l}\text { Maternal age } \\
\text { [years (Mean } \pm \text { SD)] }\end{array}$ & $22.3 \pm 3.4$ & $27.5 \pm 5.1$ \\
$\begin{array}{l}\text { Gestational age [weeks } \\
\text { (Mean } \pm \text { SD)] }\end{array}$ & $38.7 \pm 1.2$ & $39.2 \pm 1.4$ \\
$\begin{array}{l}\text { Birthweight } \\
\text { [kg. (Mean } \pm \text { SD)] }\end{array}$ & $2.8 \pm 0.9$ & $3.1 \pm 1.1$ \\
$\begin{array}{l}\text { Head circumstance } \\
\text { [cm (Mean } \pm \text { SD)] }\end{array}$ & $30.9 \pm 4.2$ & $32.4 \pm 3.7$ \\
$\begin{array}{l}\text { Apgar Score at 5 Minutes } \\
\text { (Mean } \pm \text { SD) }\end{array}$ & $7 \pm 2$ & $7 \pm 1$ \\
$\begin{array}{l}\text { 2 stage of labour } \\
\text { [minutes (Mean } \pm \text { SD)] }\end{array}$ & $78 \pm 29$ & $57 \pm 23$ \\
$\begin{array}{l}\text { Use of oxytocin [No. }(\%)] \\
\text { Status of operator [No. }(\%)]\end{array}$ & $271(24.7)$ & $357(19.6)$ \\
1. House Surgeon & $738(67.4)$ & $1042(57.2)$ \\
$\begin{array}{l}\text { 2. Medical Officer } \\
\text { 3. Senior Registrar }\end{array}$ & $301(27.5)$ & $714(39.2)$ \\
\hline
\end{tabular}

The effect of episiotomy on the incidence of perineal lacerations was estimated sepparately in primiparous and multiparous women. In primiparae, the incidence of various types of perineal lacerations with respect to episiotomy is shown in Table-V.The incidence of first degree perineal lacerations was significantly reduced $(\mathrm{P}<.00001)$ in women delivered with episiotomy as compared to those without episiotomy. Sixty three $(6.2 \%)$ primiparae delivered with episiotomy sustained first degree perineal tears as compared to $16(22.2 \%)$ tears in those delivered without episiotomy. The similar incidences of second, third and fourth degree perinal lacerations. were recorded in primiparous women who delivered with or without episiotomy.

Table VI relates incidence of perineal lacerations in multiparous women. Comparable incidences were recorded for the occurrence of first, second and third degree perineal lacerations in deliveries accomplished either with or without episiotomy. However, fourth degree perineal tears were sustained in only $0.3 \%$ of multiparae delivered without episiotomy as compare to $2.3 \%$ delivered with episiotomy. This difference has a P-Value of .0001 which is statistically highly significant.

Table-II: indications for episiotomy in study groups.

\begin{tabular}{lll}
\hline Indication & No. & \% \\
\hline Prophylactic & 675 & 47.6 \\
Facilitate $2^{\text {nd }}$ stage & 314 & 22.1 \\
Fetal distress & 186 & 13.1 \\
Not registered & 244 & 17.2 \\
Total & 1419 & 100 \\
\hline
\end{tabular}

Table-III: Cumulative incidence of perineal lacerations with and without episiotomy.

\begin{tabular}{llll}
\hline Lacerations & $\begin{array}{l}\text { With } \\
\text { Episiotomy } \\
\text { N }(\%)\end{array}$ & $\begin{array}{l}\text { Without } \\
\text { Episiotomy } \\
\mathbf{N}(\%)\end{array}$ & Sig. \\
\hline $1^{\text {st }}$ degree & $70(4.9)$ & $59(3.9)$ & $\mathrm{NS}$ \\
$2^{\text {nd }}$ degree & $54(3.8)$ & $43(2.9)$ & $\mathrm{NS}$ \\
$3^{\text {rd }}$ degree & $13(0.9)$ & $9(0.6)$ & $\mathrm{NS}$ \\
$4^{\text {th }}$ degree & $14(1)$ & $5(0.3)$ & $\mathrm{P}<.02$ \\
Total & $151(10.6)$ & $116(7.7)$ & $\mathrm{P}<.006$ \\
\hline$N S=$ Not significant. & &
\end{tabular}

Table-IV: incidence of perineal lacerations by parity.

\begin{tabular}{llll}
\hline Lacerations & $\begin{array}{l}\text { Primiparae } \\
\text { N }(\%)\end{array}$ & $\begin{array}{l}\text { Multiparae } \\
\text { N }(\%)\end{array}$ & Sig. \\
\hline $1^{\text {st }}$ degree & $79(7.2)$ & $50(2.7)$ & $\mathrm{P}<.00001$ \\
$2^{\text {nd }}$ degree & $45(4.1)$ & $52(2.8)$ & $\mathrm{NS}$ \\
$3^{\text {rd }}$ degree & $12(1.1)$ & $10(0.5)$ & $\mathrm{NS}$ \\
$4^{\text {th }}$ degree & $6(0.5)$ & $13(0.7)$ & $\mathrm{NS}$ \\
Total & $142(13)$ & $125(6.9)$ & $\mathrm{P}<.00001$ \\
\hline NS= Not significant & &
\end{tabular}

Table-IV: Incidence of perineal lacerations with and without episiotomy in primiparae.

\begin{tabular}{llll}
\hline Lacerations & $\begin{array}{l}\text { With Episi- } \\
\text { otomyN (\%) }\end{array}$ & $\begin{array}{l}\text { Without Epi- } \\
\text { siotomy N (\%) }\end{array}$ & Sig. \\
\hline $1^{\text {st }}$ degree & $63(6.2)$ & $16(22.2)$ & $\mathrm{P}<.00001$ \\
$2^{\text {nd }}$ degree & $42(4.1)$ & $3(4.2)$ & $\mathrm{NS}$ \\
$3^{\text {rd }}$ degree & $10(1)$ & $2(2.8)$ & $\mathrm{NS}$ \\
$4^{\text {th }}$ degree & $5(0.5)$ & $1(1.4)$ & $\mathrm{NS}$ \\
Total & $120(11.7)$ & $22(30.5)$ & $\mathrm{P}<.00001$ \\
\hline$N S=$ Not significant. & &
\end{tabular}


Table-VI: Incidence of perineal lacerations with and without episiotomy in multiparae.

\begin{tabular}{llll}
\hline Lacerations & $\begin{array}{l}\text { With Episi- } \\
\text { otomy N (\%) }\end{array}$ & $\begin{array}{l}\text { Without Episi- } \\
\text { otomy N (\%) }\end{array}$ & Sig. \\
\hline $1^{\text {st }}$ degree & $7(1.8)$ & $43(3)$ & $\mathrm{NS}$ \\
$2^{\text {nd }}$ degree & $12(3)$ & $40(2.8)$ & $\mathrm{NS}$ \\
$3^{\text {rd }}$ degree & $3(0.8)$ & $7(0.5)$ & $\mathrm{NS}$ \\
$4^{\text {th }}$ degree & $9(2.3)$ & $4(0.3)$ & $\mathrm{P}<.0001$ \\
Total & $31(7.8)$ & $94(6.6)$ & $\mathrm{NS}$ \\
\hline
\end{tabular}

\section{Discussion:}

This study examines the effects of episiotomy on the frequency perineal lacerations in our population. Several factors other than episiotomy are known to be associated with the incidence of perineal lacerations. An increase in the incidence of lacerations in associated with primigravid status, infant's birth weight of more than $4000 \mathrm{Grams}$, and second stage of labour lasting more than 90 minutes. Similarly, place of birth, maternal race, age and height, fetal presentation, twin gestation, instrumental deliveries, and presence of dystocia are known to be associated with increased likelihood of experiencing a perineal laceration. An attempt was made to control some of these confounding variables by excluding twin. Instrumental and preterm deliveries from the analysis. Rest of the clinical characteristics were comparable in two study groups comprising primiparae and multiparae (Table-I)

Our results indicate that in over $60 \%$ of cases, no other indication for episiotomy was present except that the attending physician regarded the procedure as protective against perineal lacerations. The rate of episiotomy was very high in our primiparous population. In overall episiotomy rate of $48.6 \%$ in our population was recorded which is comparable to the episiotomy rate reported in contemporary . The procedure was performed in $93.4 \%$ of primiparae compare to $21.7 \%$ in multiparae. These rates are also comparable to those reported in the literature. The primigravid women commonly have higher rates of episiotomy. It is reported to be as high as $95.6 \%$ in some studies. In a previous study from our institution, an episiotomy rate of $89.4 \%$ was reported in primiparae.

In present study, the primiparae were seen to be significantly more prone to first degree perineal lacerations than multiparae ( $7.2 \%$ versus $2.7 \%$ ). However parity had no significant effect on the frequency of severe perineal lacerations. The episiotomy had a protective effect in primiparae by lowering the incidence of first degree lacerations to $6.2 \%$ compared with $22.2 \%$ without episiotomy.

The increase in the incidence of fourth degree perineal lacerations associated with the use of episiotomy in our population has supported the results of previously quoted studies. Aslam (1993) reported that $1.3 \%$ women who had undergone episiotomies sustained fourth degree lacerations compared to $0.2 \%$ without episiotomy. Eltorkey et al. (1994) claim that a policy of selective use of episiotomy resulted in less perineal trauma than elective use of episiotomy.

Our findings reinforce doubts already voiced in the contemporary literature and question the current practice in many obstetric units of performing for the unsupported belief that it will prevent perineal lacerations.

\section{Conclusion:}

This study has failed to support that episiotomy is protective against severe perineal lacerations. The increased risk of fourth degree perineal lacerations with episiotomy raises serious questions about its routine use. A selective use of episiotomy is recommended for appropriate indications e.g preterm delivery, shoulder dystocia, breech delivery, instrumental deliver, occipitoposterior positions, and in cases where perineum is threatening to tear.

\section{References:}

1. Aldridge AN, Watson P, Analysis of end-results of labor in primiparas after spontaneous versus prophylactic methods of delivery. Am-J-Obstet Gynecol 1935;30:554-65.

2. Anthony S., Buitendijk S.E., Zondervan K.T., Van Russel E.J.C. Episiotomies and the occurrence of severe perineal lacerations. Br J, Obstet Gynaecol 1994;101:1064-7

3. Argentine Episiotomy Trial Collaborative Group. Routine vs selected episiotomy: a randomized controlled trial. Lancet $1993 ; 342 ; 1517-8$.

4. Aslam M. Effects of episiotomy on perineal lacerations. Specialist 1993; 9:245-24.

5. Bansal RK, Tan WM et al. Is there a benefit to episiotomy at spontaneous vaginal delivery? A natural experiment. Am JObstet Gynecol 1996'175:897-901.

6. Bek $\mathrm{Km}$, Laurberg S. Risks of anal incontinence from subsequent vaginal delivery after a complete obstetric anal sphincter tear. Br J Obstet Gynaecol 1992;99:724-6.

7. beynon CL. Midline episiotomy as a routine procedure. J Obstet Gynaecol Br Commonw 1974;81:126-30.

8. Blondel B, Kaminski M. Episiotomy and third degree tears Br J Obstet Gynaecol, 1985;02:1297-8.

9. Borgatta L, Piening SL, Cohen WR. Association of episiotomy and delivery position with deep perineal lacerations during spontaneous delivery in nulliparous women. Am J Obstet Gynecol 1989;160:294-7.

10. Brandt-Graham S, Cantanzarite V, Benstein J, VaretaGittings F.A comparison of Attitudes and practices of episiotomy among obstetrical practitioners in New Mexico. Soc Sci Med 1990;31:191-201

11. Buekens P, Lagasse R, Dramaix M, Wallast E. Episiotomy and third degree tear Br J Obstet Gynaecol, 1985;92:820-3.

12. Flood $\mathrm{C}$. The real reason for performing episiotomies. World medicine 1982; Feb 6:51.

13. Gass MS, Dunn C, Stys SJ Effects of episiotomy on the frequency of vaginal outlet lacerations. J Reprod Med 1986;31:240-44.

14. Promeroy RH. Shall we cut and reconstruct perineum for every primipara? Am J Obstet Dis Women Child, 1918;78:211.

15. Rockner G, Olund A. The use of episiotomy in primiparas in Sweden. Acta Obstet Gynacol Scand 1991;70:325-30 